\title{
Type II diabetes of early onset: A distinct clinical and genetic syndrome?
}

\author{
S O'RAHILLY, R S SPIVEY, R R HOLMAN, Z NUGENT, A CLARK, R C TURNER
}

\begin{abstract}
The inheritance of non-insulin-dependent (type II) diabetes was studied by a continuous infusion of glucose test in all available first degree relatives of $\mathbf{4 8}$ diabetic probands of various ages and with differing severity of disease. In an initial study of 38 type II diabetic subjects and their first degree relatives six islet cell antibody negative patients with early onset disease (aged 25-40 at diagnosis) were found to have a particularly high familial prevalence of diabetes or glucose intolerance. Nine of 10 parents available for study either had type II diabetes or were glucose intolerant. A high prevalence of diabetes or glucose intolerance was also found in their siblings $(11 / 16 ; 69 \%)$. In a second study of the families of a further 10 young diabetic probands (presenting age 25-40) whose islet cell antibody state was unknown a similar high prevalence of diabetes or glucose intolerance was found among parents of the five islet cell antibody negative probands $(8 /$ 9; $89 \%$ ) but not among parents of the five islet cell antibody positive probands $(3 / 8 ; 38 \%)$.

Islet cell antibody negative diabetics with early onset type II disease may have inherited a diabetogenic gene or genes from both parents. They commonly need insulin to maintain adequate glycaemic control and may develop severe diabetic complications. Early onset type II diabetes may represent a syndrome in which characteristic pedigrees, clinical severity, and absence of islet autoimmunity make it distinct from either type I diabetes, maturity onset diabetes of the young, or late onset type II diabetes.
\end{abstract}

\section{Introduction}

Non-insulin-dependent (type II) diabetes is known to have a strong familial basis. Nearly complete concordance is found in identical twins ${ }^{1}$ and the few apparently unaffected twins of type II diabetics have been found to have abnormal glucose tolerance. ${ }^{2}$ Extensive studies of relatives have failed to show a pattern of inheritance conforming to a simple mendelian hypothesis, ${ }^{3}$ though the bimodality of glucose tolerance found in populations with an extremely high prevalence of type II diabetes suggests a major single gene effect. ${ }^{45}$ The failure to find bimodality in white populations may reflect either the polygenic nature of the disorder ${ }^{3}$ or heterogeneity within the disease with type II diabetes encompassing various disorders. ${ }^{6}$ Environmental influences are plainly crucial to the expression of the condition in predisposed subjects, obesity being a main factor. ${ }^{7}$ The description of maturity onset diabetes of youth in 1974, with its apparent autosomal dominant transmission, ${ }^{89}$ represented an advance in the attempt to define the specific disorders which make up type II diabetes.

Kobberling attempted to clarify the genetic heterogeneity of type II diabetes by assessing the frequency of a positive family history of diabetes in relation to the sex, obesity, and treatment of diabetic probands. ${ }^{10} \mathrm{~A}$ greater prevalence of known diabetes was found in the relatives of non-obese, insulin treated patients than in the relatives of obese patients treated by diet alone, suggesting a greater role for genetic factors in the former. Diabetes often goes undiagnosed, which imposes severe limitations on studies relying on family history. Several studies of apparently unaffected relatives given an oral glucose tolerance test have shown a high prevalence of abnormality. ${ }^{112}$ Many of these studies were performed before the separation of type I and type II diabetes and so are difficult to interpret.

We have studied both glucose tolerance and insulin secretion in families of patients with type II diabetes. ${ }^{13} \mathrm{~A}$ continuous infusion of glucose for one hour, with a dose related to ideal body weight, ${ }^{14}$ results in plasma glucose concentrations similar to postprandial values, and the steady increase in plasma glucose aids assessment of glucose tolerance. In an initial study of 38 type II diabetics and their families a high prevalence of diabetes and glucose intolerance was found in the first degree relatives of patients presenting before the age of 40. A second study was undertaken of families of a further 10 patients who presented between 25 and 40 years of age and whose 
islet cell antibody state was initially unknown, and a similar high familial prevalence of glucose intolerance and diabetes was found in the families of those who did not have islet cell antibodies. Early onset type II diabetes seems to be an inherited form of diabetes directly related to late onset type II diabetes but genetically distinct from type I diabetes and maturity onset diabetes of youth.

\section{Subjects and methods}

A study of the prevalence of diabetes and glucose intolerance in families of patients with type II disease was approved by the Oxford ethics committee and informed consent obtained from all subjects.

Probands in study 1 -Thirty three white diabetic probands with type II disease who had one or more relatives in the Oxford area willing to be studied were recruited. All patients attending either the Oxford clinic of the United Kingdom prospective diabetes study or a routine diabetic clinic over three months were asked whether they had one or more first degree relatives in the Oxford area who might be willing to be tested. Only subjects who had at least one non-diabetic relative who was available for testing were recruited as probands. Tests for islet cell antibodies were performed on the presenting serum of any proband suspected of having type I diabetes (age below 40 at presentation or fasting plasma glucose concentration exceeding $15 \mathrm{mmol} / 1$ in a non-obese person) and a positive result obtained in three; these subjects were excluded from the study. Thirty probands were from the 250 patients in the Oxford clinic of the United Kingdom prospective diabetes study and three from the routine diabetic clinic. Seventeen of these probands had a first degree relative with known diabetes, five of whom had other first degree relatives-namely, children - available for study; these five subjects were included as additional probands. None of the $\mathbf{3 8}$ probands had ketonuria greater than + (Ketostix, Ames) at presentation and all had been treated by diet or tablets for at least three months. The probands were aged 32-64 at presentation (mean 51 (SD 12) years); 17 were men and 21 women; and their mean percentage of ideal body weight was 130 (SD 28). The prevalence of a positive family history in the recruited probands accorded with that found on detailed questioning by other workers and was unlikely to represent a source of bias. ${ }^{10}$

Probands in study 2-A high prevalence of glucose intolerance was found in the first degree relatives of diabetics presenting at 25-40 years of age. Some of these subjects were identified through a relative with diabetes. Though this did not affect the high prevalence of newly discovered glucose intolerance, it did affect the total number of relatives with known diabetes. To see whether the high familial prevalence could be confirmed we carried out a second study of a further 10 diabetic probands presenting between 25 and 40 years of age (mean 32 (SD 5)). All subjects attended the diabetic clinic and two were ascertained through diabetic siblings. No subjectihad a history of ketosis and none began insulin at the time of diagnosis. Eight of the 10 were currently being treated with insulin and two with oral hypoglycaemic agents. Islet cell antibody state was unknown at the time of study but was assessed subsequently. As part of the United Kingdom diabetes study protocol eight of the 10 subjects had plasma stored from the time of presentation with diabetes, and islet cell antibody tests were performed on this sample. Of the two subjects who did not have plasma stored at presentation, one was positive for islet cell antibodies and one negative.

First degree relatives of diabetic probands - In both studies a detailed pedigree was obtained from each proband and repeatedly cross checked when the relatives attended for study. A history of diabetes in a first degree relative was confirmed, when possible, by contacting that relative. Once a relative was studied every effort was made to examine all members of his or her sibship. To reduce reliance on family history data only sibships and parents in whom at least one member was tested by continuous infusion of glucose were included in the study.

Continuous infusion of glucose test-Subjects took a weight maintaining diet containing $200 \mathrm{~g}$ or more carbohydrate for at least three days before the continuous infusion of glucose test. Details of the test are reported elsewhere. ${ }^{14}$ Briefly, it consisted of a continuous intravenous infusion of $5 \mathrm{mg}$ glucose/kg ideal body weight/min for 60 minutes, ideal body weight being taken from the Metropolitan Life Insurance tables for a medium frame. ${ }^{\text {is }}$ The achieved plasma glucose value is the mean of the 50,55 , and 60 minute samples and serves as the measure of glucose tolerance. The achieved plasma insulin and $C$ peptide concentrations are the mean insulin and $C$ peptide values for the same samples. There was a small but significant linear increase of achieved plasma glucose value with age in control subjects. ${ }^{13}$ The value was corrected to a standard age of 40 from this age related trend, as: corrected achieved plasma glucose $(\mathrm{mmol} / \mathrm{l})=6.95 \pm 0.02$ age (years). In this paper achieved plasma glucose refers to the value corrected to age 40 , and subjects with values more than 2 standard deviations above the mean of the controls $(>9 \cdot 3 \mathrm{mmol} / \mathrm{l})$ are termed glucose intolerant.
Laboratory methods-Insulin ${ }^{16}$ and $C$ peptide ${ }^{17}$ were assayed by a charcoal phase separation radioimmunoassay. Plasma glucose was measured by using hexokinase with a Cobas Bio centrifugal analyser. Islet cell antibodies were assessed by an immunofluorescence technique. ${ }^{18}$

Analysis of data-The frequency of glucose intolerance or known diabetes, or both, was compared in the relatives of probands of differing obesity, sex, and age at onset. Probands whose body weight exceeded $120 \% \widehat{\widehat{C}}$ of ideal were termed obese and those with weights below $120 \%$ of ideal nonobese. Diabetes in probands presenting before the age of 40 was termed early $D$ onset and in those presenting after age 40 late onset. The small number of $\mathbb{\infty}$ early onset cases among the 38 original probands in study 1 prompted a m separate analysis which included four additional early onset cases in relatives (see below). The term hyperglycaemic abnormality was used to describe $\ddot{\Rightarrow}$ relatives with known diabetes or glucose intolerance or those currently with $\stackrel{\vec{D}}{\rightarrow}$ gestational diabetes. We assumed that on average untested relatives would $\bar{O}$ have the same ratio of glucose intolerant to normal subjects as their tested $\frac{C}{0}$ siblings. In order to compare insulin and $C$ peptide secretion in the glucose $\bar{\omega}$

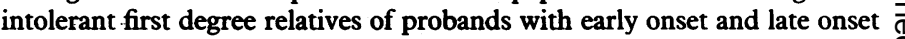
disease nine glucose intolerant relatives of early onset probands (age under 40 ; less than $120 \%$ of ideal body weight) were identified. These were is compared with nine matched glucose intolerant relatives of late onset $\vec{\circ}$ diabetics. Their mean ages were 42 and 40 years, respectively; mean body weights $111 \%$ and $112 \%$ of ideal, respectively; and mean achieved plasma glucose values 10.0 and $9.7 \mathrm{mmol} / \mathrm{l}$, respectively. Both groups were compared with 44 normal controls matched for age and weight (mean age 44; mean $110 \%$ of ideal body weight).

Statistical analysis-Except where stated otherwise data are presented as mean and standard deviation (SD). Statistical analysis of insulin and $C$ peptide data used log transformed values, and results are given as of geometric means. Comparisons between groups were by unpaired $t$ test. Frequencies were assessed by $\chi^{2}$ or Fisher's exact test for small numbers. $ं$ In the analysis of siblings or children inclusion of more than one relative $N$ of a proband means that theoretically their data were not statistically $\mathrm{O}$ independent. There are obviously considerable differences between siblings in many families, however, and no statistical correction was made as we were $\overrightarrow{-}$ uncertain whether or to what extent this would be necessary. This did not affect the study of parents. Non-significance was taken as $p \geqslant 0.05$.

Controls-Sixty four healthy normal volunteers served as controls. Thirty eight were men and 26 women; their mean age was 44 (20) years; and their $ळ$ mean percentage of ideal body weight was 109 (18). None was taking any ? medication known to influence glucose tolerance and none had a history of diabetes in first degree relatives.

\section{Results}

STUDY I

\section{Relatives of patients with type II disease}

Fifteen of the 163 first degree relatives in the study were already known to be diabetic and two had current gestational diabetes. Twenty eight of the 124 relatives who were not known to be diabetic were glucose intolerant with an achieved plasma glucose value more than $2 \mathrm{SD}$ above the age corrected mean of the normal subjects. Three of these 28 subjects had diabetes by World Health Organisation criteria (fasting plasma glucose concentration over $7.8 \mathrm{mmol} / \mathrm{l}$ ) and a further six had a fasting plasma glucose value exceeding $6 \mathrm{mmol} / \mathrm{l}$. Twenty two relatives could not be studied: four were dead, eight $\mathrm{O}$ refused, and 10 were inaccessible.

\section{Age at onset of diabetes}

Two of the 38 original probands (cases 1 and 2; table I) had developed diabetes before age 40 . Both were negative for islet cell antibodies and had $\sigma$ required insulin to achieve a fasting plasma glucose concentration below 0 $10 \mathrm{mmol} / 1$ after a short period taking diet and oral hypoglycaemic agents. Neither had a first degree relative with known diabetes but both had uncles $\mathscr{O}$ or aunts with type II disease.

Prevalence of glucose intolerance in parents-All four parents of the initial two probands were tested and found to be abnormal, one with undiagnosed $\mathbb{\mathbb { D }}$ diabetes (fasting plasma glucose value $15.7 \mathrm{mmol} / 1$; fig 1 ) and the three others with glucose intolerance (achieved plasma glucose concentrations $9 \cdot 8, \Omega$ $9 \cdot 4$, and $10.8 \mathrm{mmol} / 1)$. To see whether this pattern was common we examined the families of the four islet cell antibody negative diabetic relatives in the study who had developed diabetes between 25 and 40 years of age. These four subjects were not among the original 38 probands. Table I gives the details of all six early onset cases. Bias towards finding diabetes in relatives of the early onset group was inevitable, as two were ascertained 
TABLE I-Details of diabetic patients in study 1 who presented at 25-40 years of age (early onset)

\begin{tabular}{|c|c|c|c|c|c|c|c|c|c|c|}
\hline $\begin{array}{l}\text { Case } \\
\text { No }\end{array}$ & $\begin{array}{c}\text { Age at } \\
\text { diagnosis } \\
\text { (years) }\end{array}$ & $\begin{array}{c}\% \text { Ideal } \\
\text { body weight } \\
\text { at diagnosis }\end{array}$ & Sex & $\begin{array}{l}\text { Presenting } \\
\text { symptoms }\end{array}$ & $\begin{array}{c}\text { Fasting plasma } \\
\text { glucose at } \\
\text { diagnosis }(\mathrm{mmol} / \mathrm{l})\end{array}$ & $\begin{array}{l}\text { Initial } \\
\text { treatment }\end{array}$ & $\begin{array}{c}\text { Duration } \\
\text { of initial } \\
\text { treatment }\end{array}$ & $\begin{array}{c}\text { Current } \\
\text { treatment }\end{array}$ & Ascertainment & $\begin{array}{l}\text { Islet cell } \\
\text { antibody } \\
\text { state }\end{array}$ \\
\hline $1^{\star}$ & 35 & 91 & $\mathbf{F}$ & Thirst, polyuria & $16 \cdot 4$ & Tablets & 10 months & Insulin & United Kingdom diabetes study proband & Negative \\
\hline $2^{\star}$ & 34 & 175 & $\mathbf{F}$ & Vaginal candidiasis & $19 \cdot 0$ & Diet & 3 months & Insulin & United Kingdom diabetes study proband & Negative \\
\hline $3+$ & 39 & 102 & $\mathbf{M}$ & Balanitis & $16 \cdot 5$ & Tablets & 8 years & Insulin & $\begin{array}{l}\text { Brother of United Kingdom diabetes study } \\
\text { proband }\end{array}$ & Negative \\
\hline $4 \dagger$ & 36 & 174 & $\mathbf{F}$ & Incidental & $7 \cdot 1$ & Diet & 7 months & Diet & $\begin{array}{l}\text { Sister of United Kingdom diabetes study } \\
\text { proband }\end{array}$ & Negative \\
\hline $5+$ & 34 & 103 & $M$ & Polyuria, weight loss & $19 \cdot 4$ & Tablets & 7 years & $\begin{array}{l}\text { Maximum } \\
\text { tablets }\end{array}$ & $\begin{array}{l}\text { Son of United Kingdom diabetes study } \\
\text { proband }\end{array}$ & Negative \\
\hline $6 \dagger$ & 30 & 99 & $M$ & Incidental glycosuria & $7 \cdot 0$ & Diet & 9 months & Diet & $\begin{array}{l}\text { Son of United Kingdom diabetes study } \\
\text { proband }\end{array}$ & Negative \\
\hline
\end{tabular}

$\star$ Original proband.

†First degree relative with early onset diabetes.

TABLE II-Prevalence of intolerance to continuous infusion of glucose (age corrected achieved plasma glucose concentration $>2$ SD above control mean) and of any hyperglycaemic abnormality (diabetes, gestational diabetes, or intolerance of continuous infusion of glucose) in relatives of six early onset (age 25-40) and 35 late onset (age $>40$ ) diabetics in study 1

\begin{tabular}{|c|c|c|c|c|c|c|c|}
\hline & & \multicolumn{3}{|c|}{ Glucose intolerance } & \multicolumn{3}{|c|}{ All hyperglycaemic abnormalities } \\
\hline & & Parents & Siblings & Children & Parents & Siblings & Children \\
\hline Prevalence (\%) & $\left\{\begin{array}{l}\text { Early onset probands } \\
\text { Late onset probands }\end{array}\right.$ & $\begin{array}{l}6 / 7(85 \cdot 7) \\
1 / 7(14 \cdot 3)^{\star}\end{array}$ & $\begin{array}{l}5 / 9(55 \cdot 6) \\
7 / 28(25 \cdot 0)\end{array}$ & $10 / 74(13 \cdot 5)^{\star \star}$ & $\begin{array}{l}11 / 12(91 \cdot 7) \\
3 / 10(30 \cdot 0)^{\star \star}\end{array}$ & $\begin{array}{l}11 / 16(68 \cdot 8) \\
12 / 39(30 \cdot 8)^{\star \star}\end{array}$ & $16 / 90(17 \cdot 8)^{\star \star \star}$ \\
\hline Mean age in years $(\mathrm{SD})$ & $\left\{\begin{array}{l}\text { Early onset probands } \\
\text { Late onset probands }\end{array}\right.$ & $\begin{array}{l}63(6) \\
73(4)^{\star \star}\end{array}$ & $\begin{array}{l}39(10) \\
53(11)^{\star \star \star}\end{array}$ & $29(7)^{\star \star \star}$ & $\begin{array}{l}64(6) \\
74(6)^{\star \star}\end{array}$ & $\begin{array}{l}39(10) \\
54(12)^{\star \star \star}\end{array}$ & $30(8)^{\star \star \star}$ \\
\hline \% Ideal body weight (SD) & $\left\{\begin{array}{l}\text { Early onset probands } \\
\text { Late onset probands }\end{array}\right.$ & $\begin{array}{l}130(28) \\
130(28)\end{array}$ & $\begin{array}{l}126(13) \\
118(20)\end{array}$ & $118(22)$ & $\begin{array}{l}130(8) \\
130(28)\end{array}$ & $\begin{array}{l}126(13) \\
118(28)\end{array}$ & $118(22)$ \\
\hline
\end{tabular}

Late onset $v$ early onset groups (children of late onset group compared with siblings of early onset group): ${ }^{\star} \mathrm{p}<0.05 ;{ }^{\star \star} \mathrm{p}<0.01 ;{ }^{\star \star \star} \mathrm{p}<0.001$.

through a parent and two through a sibling with known diabetes. This should not, however, affect the results of the continuous infusion of glucose tests in the relatives who were not known to be diabetic. The four additional subjects with early onset disease were not counted as relatives of probands. The sample number in this analysis therefore differed slightly from that in subsequent analyses as a result of including these extra subjects as probands. Of the four additional early onset diabetics, five of their six living parents had glucose intolerance (fig 2). The sixth had both fasting and achieved plasma glucose values $(5 \cdot 8$ and $9 \cdot 2 \mathrm{mmol} / \mathrm{l}$, respectively) in the upper normal range. By contrast, few of the late onset diabetics (presenting age over 40) had parents alive or available to attend for a test. Of the seven such parents (five families), only one had glucose intolerance, a significantly smaller proportion ( $p=0.014$ ) than that among the younger parents of the early onset group. The parents of subjects with early onset disease also had a

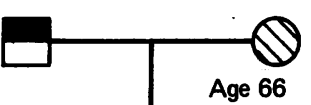

FPG 15.7 APG 20-4

FPI $5 \cdot 3$ API $4 \cdot 6$

FPG 5.9 APG 10.2

FPI 3.5 API 15.9

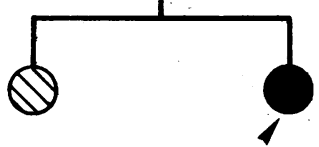

Age 44

FPG 5.8 APG 9.8

FPI 4.0 API $11 \cdot 7$

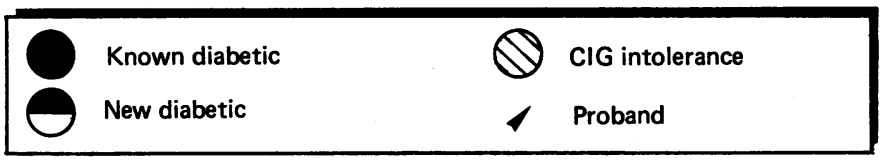

FIG 1-Results of continuous infusion of glucose test in family of early onset diabetic proband in study 1 (case 1 ; table I). FPG=Fasting plasma glucose concentration $(\mathrm{mmol} / \mathrm{l})$. APG $=$ Achieved plasma glucose concentration $(\mathrm{mmol} / \mathrm{l})$. FPI $=$ Fasting plasma insulin concentration $(\mathrm{mU} / \mathrm{l})$. API =Achieved plasma insulin concentration $(\mathrm{mU} / \mathrm{l})$. CIG=Continuous infusion of glucose.
1
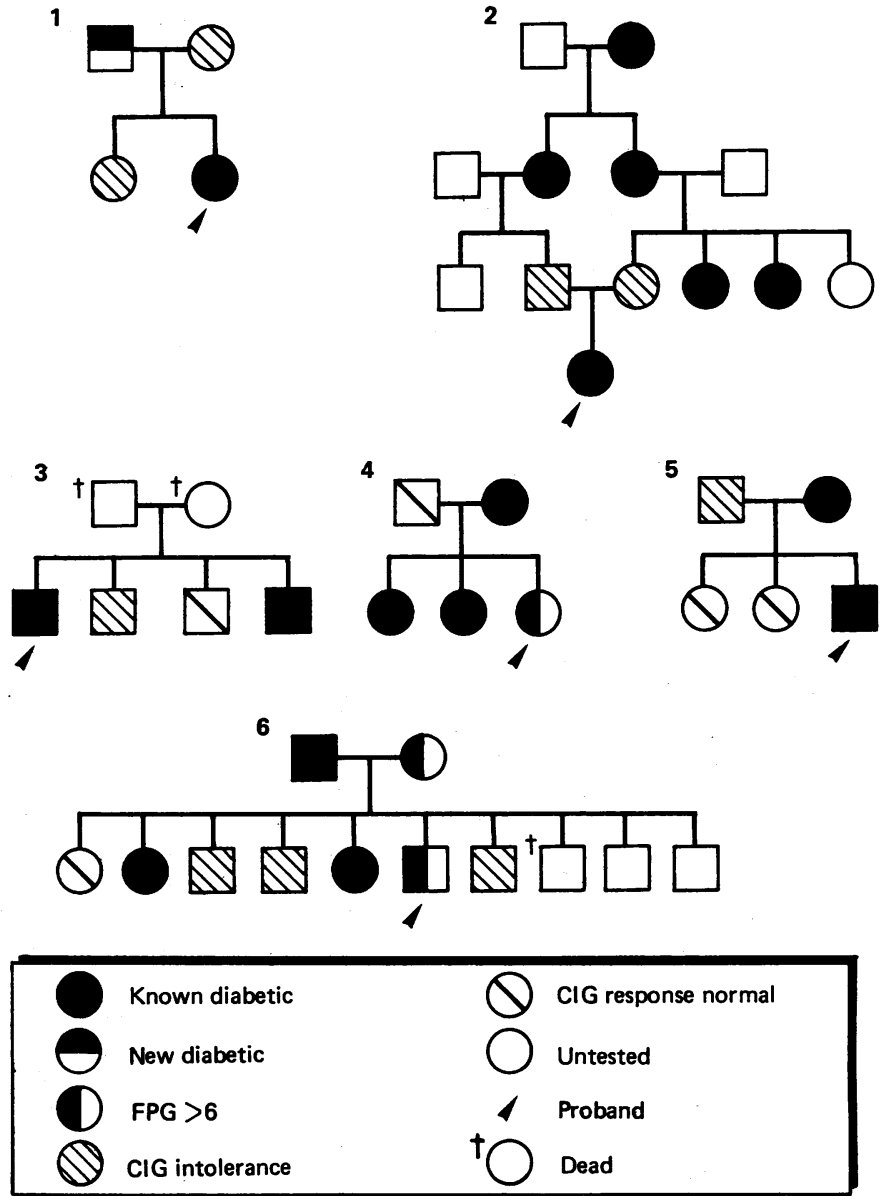

FIG 2-Family trees of six islet cell antibody negative early onset diabetics in study 1 (cases 1-6; table I). FPG = Fasting plasma glucose concentration $(\mathrm{mmol} / \mathrm{l})$. $\mathrm{CIG}=$ continuous infusion of glucose. 
TABLE III-Details of diabetic patients in study 2 who presented at 25-40 years of age (early onset) who had not been ketotic and were not known to be positive for islet cell antibodies initially. (Patients grouped according to subsequent islet cell antibody state)

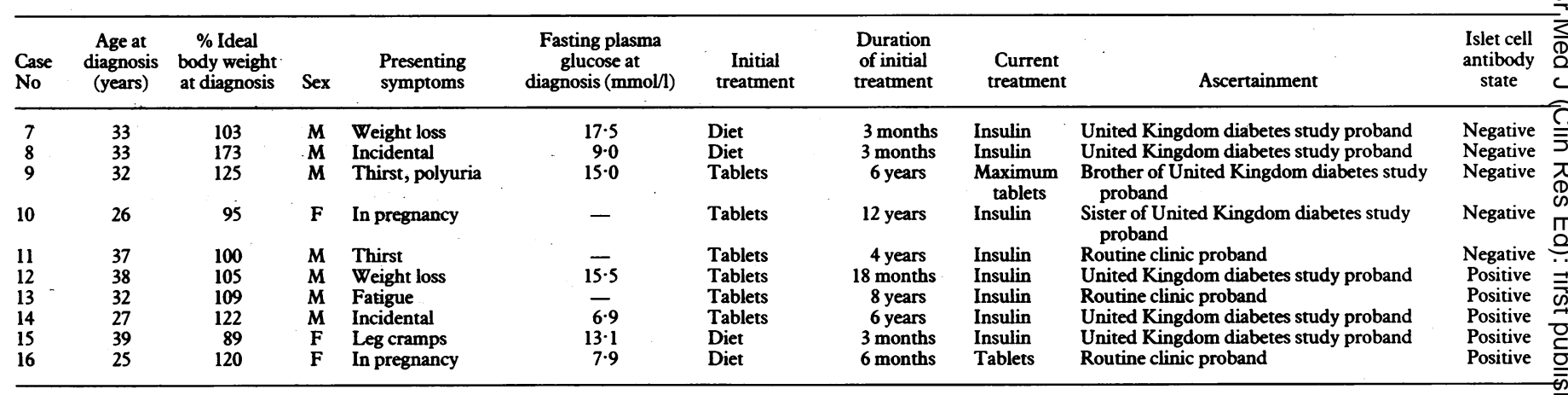

TABLE IV-Details of patients with islet cell antibody negative early onset type II diabetes and severe microvascular complications

\begin{tabular}{|c|c|c|c|c|c|c|c|c|}
\hline $\begin{array}{l}\text { Age at } \\
\text { diagnosis } \\
\text { (years) }\end{array}$ & $\begin{array}{c}\text { Duration of } \\
\text { diabetes } \\
\text { (years) }\end{array}$ & $\begin{array}{c}\% \text { Of ideal } \\
\text { body weight } \\
\text { at diagnosis }\end{array}$ & Sex & $\begin{array}{l}\text { Presenting } \\
\text { symptoms }\end{array}$ & $\begin{array}{c}\text { Initial } \\
\text { treatment }\end{array}$ & $\begin{array}{l}\text { Duration of } \\
\text { initial treat- } \\
\text { ment (years) }\end{array}$ & $\begin{array}{l}\text { Current } \\
\text { treatment }\end{array}$ & Complications \\
\hline
\end{tabular}

*Case 11.

tCase 3.

significantly higher prevalence of any hyperglycaemic abnormality than the parents of the late onset group ( $p<0.005$; table II).

Prevalence of glucose intolerance in siblings-An excess of glucose intolerance was found in the siblings (mean age 39 (10) years) of subjects in the early onset group when compared with the slightly younger children (mean age 29 (7) years) of the late onset group $(5 / 9(56 \%) v 10 / 74(14 \%) ; p<0 \cdot 005)$ but not when compared with the slightly older siblings (mean age 53 (11) years) of the late onset group $(5 / 9(56 \%) v 7 / 28(25 \%)$; NS) (table II). The excess prevalence of glucose intolerance in siblings of younger children was also found when these two comparison groups were combined to give a similar age (36 (12) years; $5 / 9 v 17 / 105 ; \mathrm{p}<0.005)$. A high prevalence of any hyperglycaemic abnormality $(11 / 16 ; 69 \%)$ was found in the siblings of the early onset group, though there was some bias; two subjects in the early onset group were ascertained through diabetic siblings.

\section{Sex}

The 17 male and 21 female probands had similar proportions of relatives with glucose intolerance $(15 / 61(25 \%) v 13 / 63(21 \%)$; NS) and any hyperglycaemic abnormality (27/80 (34\%) v 23/83 (28\%); NS).

\section{Obesity}

The relatives of 18 non-obese probands ( $<120 \%$ of ideal body weight) did not have a higher prevalence of glucose intolerance than the relatives of 20 obese probands $(18 / 60(30 \%) v 10 / 64(16 \%)$; NS) but did have a higher prevalence of any hyperglycaemic abnormality $(37 / 90(41 \%) v 13 / 73(18 \%)$; $\mathrm{p}<0.005)$. The high prevalence of both glucose intolerance and any hyperglycaemic abnormality found in the relatives of subjects with early onset disease was independent of obesity. The relatives of the non-obese, late onset diabetic subjects had a greater prevalence of any hyperglycaemic abnormality than the relatives of the obese late onset diabetics $(p<0.005)$.

\section{STUDY 2}

Figure 3 shows the family trees of the 10 subjects who presented at $25-40$ years of age. Islet cell antibody testing was done after the study of relatives and showed five islet cell antibody negative and five islet cell antibody positive probands. Eight of nine living parents of the five islet cell antibody negative probands were either known diabetics or glucose intolerant compared with three of eight parents (ratio adjusted for one untested parent, see methods) of the five islet cell antibody positive probands $(p<0.05)($ fig 3$)$
Islet cell antibody negative
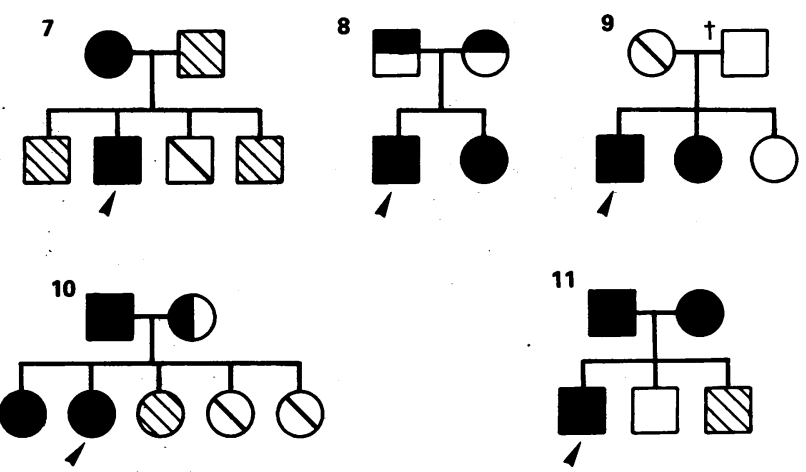

Islet cell antibody positive

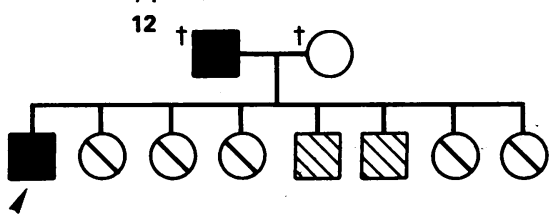

13
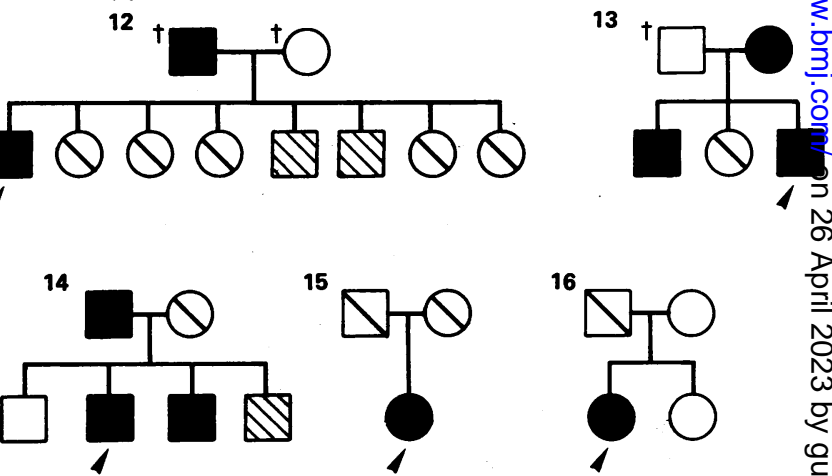

16
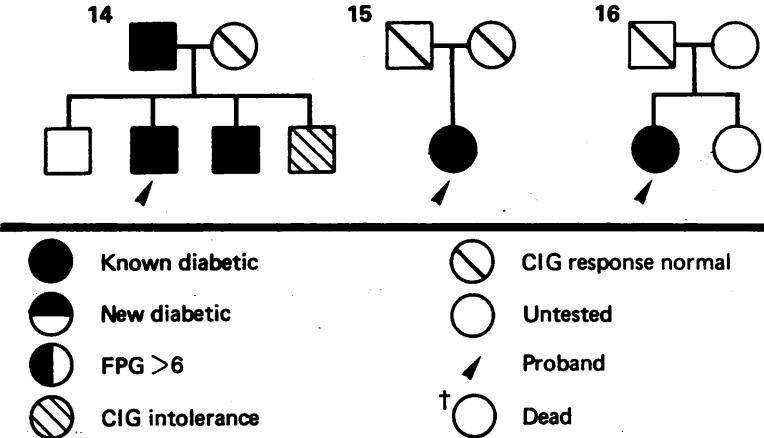

- cig response normal

$\bigcirc$ Untested

1 Proband

$+\bigcirc$ Dead

FIG 3-Family trees of 10 early onset diabetics in study 2 (cases 7-16; table III grouped according to subsequent islet cell antibody state (that is, as assessed afte families were studied). All patients were white except in case 11 (Omani). FPG Fasting plasma glucose concentration $(\mathrm{mmol} / \mathrm{l}) . \mathrm{CIG}=$ Continuous infusion oft. glucose. 
The ninth parent of the islet cell negative probands had fasting and achieved plasma glucose values $(5.6$ and $9.2 \mathrm{mmol} / 1$, respectively) in the upper normal range. There was a non-significant excess of affected siblings in the islet cell antibody negative probands compared with the islet cell antibody positive probands $(8 / 11 v 5 / 13)$. Table III summarises the details of the 10 subjects.

\section{PEPTIDE RESPONSES}

Both the first phase (0-10 minutes) and second phase (10-60 minutes) $C$ peptide responses were reduced in the glucose intolerant relatives of the early onset diabetic probands $(p<0.01$ and $p<0.01$, respectively) and glucose intolerant relatives of the late onset diabetic probands $(p<0.01$ and $\mathrm{p}<0.05$, respectively) (fig 4).
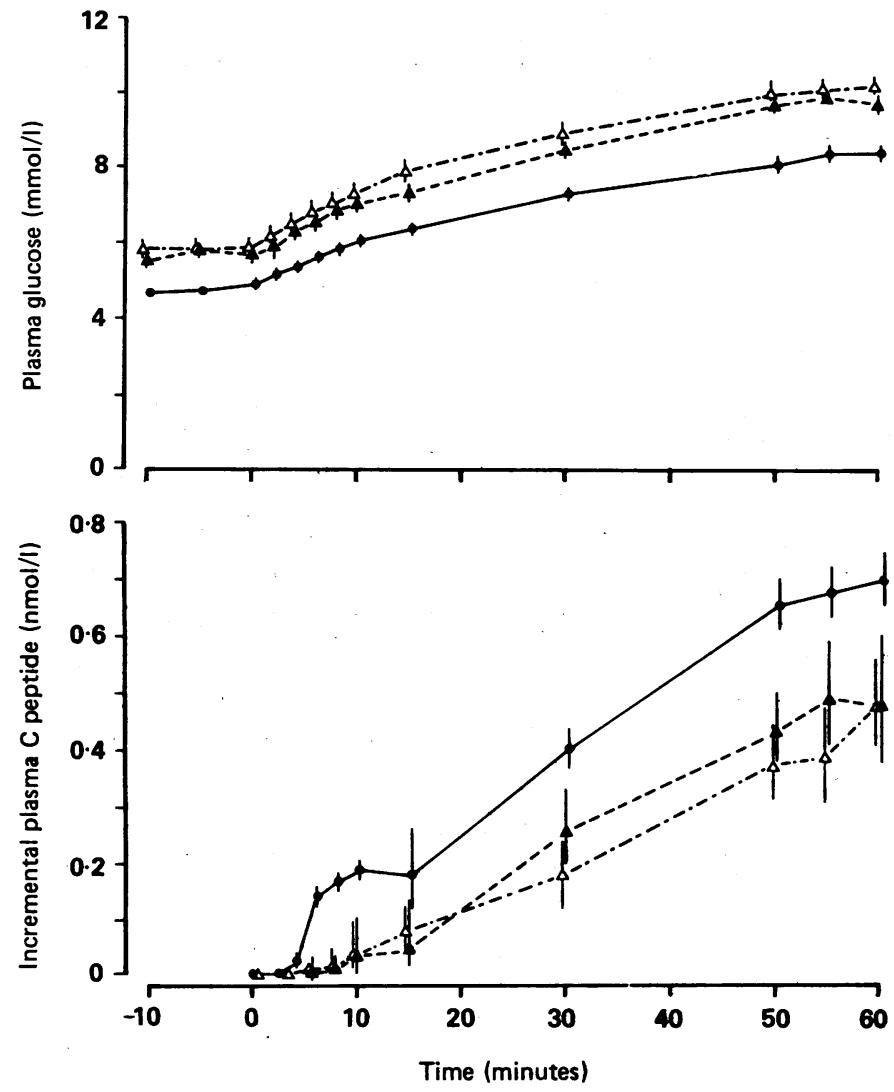

FIG 4-Incremental plasma $C$ peptide responses to glucose infusion in nine glucose intolerant relatives of early onset diabetics $(\triangle)$, nine matched glucose intolerant relatives of late onset diabetics $(\Delta)$, and 44 matched normal healthy subjects $(\mathbf{O})$. Points are means. Bars are SD.

\section{EARLY ONSET TYPE II DIABETES AND COMPLICATIONS}

Islet cell antibody negative patients with early onset type II diabetes may develop severe complications from their disease. Table IV gives four examples and includes two patients from studies 1 and 2 and two patients from a routine clinic; these two patients had two parents with late onset disease and also a high prevalence of diabetes in siblings. All four patients had severe microvascular complications. Two subjects had had known diabetes for only seven or eight years, having been treated for most of this time with oral hypoglycaemic agents.

\section{Discussion}

Our first study identified diabetes or glucose intolerance in nine of 10 living parents of six islet cell antibody negative subjects with type II disease aged between 25 and 40 at presentation. In a second study examination of the families of a further 10 patients with early onset disease showed a similar pattern, with eight of nine parents of five islet cell antibody negative probands being glucose intolerant. It may be noteworthy that the only two tested parents who were classified as normal had both fasting plasma glucose and achieved plasma glucose concentrations at the upper end of the normal range. The early presentation of type II diabetes may be due to the inheritance of diabetogenic genes from both parents. The high $(69 \%)$ prevalence of glucose intolerance found in the siblings of diabetics with early onset familial type II disease was similar to the $75 \%$ expected from mendelian calculations, assuming homozygosity in the early onset group. Though polygenic inheritance is not excluded, the data are consistent with an autosomal genetic disorder which presents at an early age when homozygous, and when heterozygous either leads to late onset diabetes or remains as lifelong subclinical glucose intolerance. The heterozygous state probably requires additional genetic or environmental factors for its expression as clinical diabetes. We found that $30 \%$ of sibs of patients with late onset disease had diabetes or glucose intolerance. Kobberling calculated that $43 \%$ of the sibs of type II diabetics would become diabetic if they all lived to age $80,{ }^{10}$ which is close to the expected $50 \%$ prevalence, assuming heterozygosity in subjects with late onset disease.

If the phenomenon of two mildly affected parents producing a more severely affected offspring were common it might have been noted more frequently in the studies of the offspring of conjugal diabetics. ${ }^{192}$ Many of these studies were performed before the separation of type I and type II diabetes, ${ }^{21}$ and if parents had different types of diabetes, including non-genetic diabetes or specific entities such as maturity onset diabetes of youth, ${ }^{9}$ we should not expect a particularly high prevalence of diabetes in their offspring. By taking patients with early onset type II diabetes and studying their parents we have increased the probability of identifying pedigrees with a specific type of familial diabetes. Viswanathan et al have reported that $30 \%$ of the diabetic offspring of conjugal diabetic parents in Madras developed the disease before the age of $40 .{ }^{22}$ This high frequency of early onset diabetes might result from both the high prevalence of diabetes and genetic homogeneity of their population, which would increase the chances of children receiving a "double dose" of diabetogenic genes from their similarly affected parents.

Harris in 1950 examined the family histories of 1241 diabetic probands and suggested as a "useful working hypothesis" that "many of the late onset mild cases could be regarded as heterozygous for a gene which in homozygous form gives rise to the early onset form." ${ }^{23}$ Subsequently the identification of immunological abnormalities and HLA associations of "juvenile onset" diabetes and their absence in maturity onset diabetes indicated the existence of two quite distinct aetiological types of diabetes. ${ }^{24}$ The suggestion of juvenile onset diabetes being a homozygous diabetic genotype was discarded, but it might be applicable to an early onset type II diabetic syndrome distinct from type I diabetes.

Clinically the distinction between type I and early onset type II diabetes may be blurred, as illustrated by the islet cell antibody positive patients with a chronic or subacute course. An abrupt onset with ketosis was not found in our type II families. Wilson $e t$ al studied 100 newly presenting patients who required insulin but did not require admission to hospital. ${ }^{25}$ Forty four were islet cell antibody negative and did not have an HLA haplotype conferring susceptibility to type I diabetes. Possibly some may have had early onset type II diabetes even though they required insulin in doses similar to patients with type I disease. This would be supported if a high familial prevalence of type II diabetes and glucose intolerance were found:

Maturity onset diabetes of youth was characterised by mild diabetes presenting in childhood with an apparent autosomal dominant mode of inheritance.$^{8926}$ None of the families in our study had onset of type II diabetes before the age of 25 or a pedigree with known diabetes which was obviously dominantly inherited. The prevalence of glucose intolerance in the parents and siblings of the islet cell antibody negative diabetics with early onset disease was greater than the $50 \%$ expected from a simple autosomal dominant gene. The term maturity onset diabetes of youth or non-insulindependent diabetes in the young has recently loosely been applied 
to any patients with familial type II diabetes presenting in the 25-35 years age range, ${ }^{27}$ but more stringent application of the original criteria may delineate a distinct disease entity. Autosomal dominant inheritance may wrongly be assumed unless the apparently unaffected parent is studied using a sensitive glucose tolerance test.

The inherited component of familial type II diabetes may be an impaired insulin secretory response of the $\beta$ cell $^{1328}$ which is exacerbated by age and the increasing demands on the $\beta$ cell which occur as insulin sensitivity decreases with increasing obesity and inactivity. ${ }^{29}{ }^{30}$ The glucose intolerant relatives of patients with either early onset or late onset type II diabetes had a similar reduction in insulin secretion, suggesting that both types might have the same hereditary defect of $\beta$ cell secretion. ${ }^{13}$ Their different age at onset may partly be due to the gene load.

Severe microvascular disease was found in some of our patients with early onset familial type II diabetes; this is in contrast with subjects with maturity onset diabetes of youth, who appear to be comparatively free of complications, ${ }^{26}$ though this is disputed. ${ }^{6}$ All our patients with microvascular disease had a long history of oral hypoglycaemic treatment before beginning treatment with insulin and may have had hyperglycaemia for years.

This study was supported by a grant from the Oxford Medical School Research Fund Committee. SO'R is the Redcliffe-Maud fellow of the British Diabetic Association, and RRH is a senior Novo research fellow at Green College, Oxford. We are grateful for the help of Dr David Matthews, Dr John Hosker, Ms Suzy Oakes, Mrs Glynis Davies, Dr Lee Suan Teh, Mrs Melanie Burnett, and Mrs Pauline Darling and to Miss Rachel Church for preparing the manuscript.

\section{References}

1 Barnett AH, Eff C, Leslie RDG, Pyke DA. Diabetes in identical twins: a study of 200 pairs. Diabetologia 1981;20:87-93.

2 Barnett AH, Spiliopoulos AJ, Pyke DA, Stubbs WA, Burrin J, Alberti KGMM. Metabolic studies in unaffected co-twins of non-insulin dependent diabetics. Br Med F 1981;282:1656-8.

3 Rotter J, Rimoin D. The genetics of the glucose intolerance disorders. Am f Med 1981;70:116-24. 4 Rushforth NB, Bennett PH, Sternberg AG, Burch TA, Miller M. Diabetes in the Pima indians; evidence of bimodality in glucose tolerance distributions. Diabetes 1971;20:756-65.
5 Zimmet $P$, Whitehouse $S$. Bimodality of fasting and two-hour glucose tolerance distributions in a Micronesian population. Diabetes 1978;27:793-800.

6 Fajans SS, Cloutier MC, Crowther RL. Clinical and etiologic heterogeneity of idiopathic diabetes 0 mellitus. Diabetes 1978:27:1112-25.

7 Beaty T, Neel J, Fajans S. Identifying risk factors for diabetes in first degree relatives of noninsulin dependent diabetic patients. Am f Epidemiol 1982;115:380-97.

8 Tattersall RB. Mild familial diabetes with dominant inheritance $Q 7$ Med 1974;43:339-57.

9 Tattersall RB, Fajans $S$. A difference between the inheritance of classical juvenile-onset and maturity-onset type diabetes of young people. Diabetes 1975;24:44-53.

10 Kobberling J. Studies on the genetic heterogeneity of diabetes mellitus. Diabetologia 1971;7:46-9.

11 Keen H, Track NS. Age of onset and inheritance of diabetes: the importance of examining relatives. Diabetologia 1968;4:317-21.

12 Thompson GS. Genetic factors in diabetes mellitus studied by the oral glucose tolerance test. f Med Genet 1965;2:221-6.

13 O'Rahilly SP, Nugent Z, Rudenski AS, et al. Beta-cell dysfunction, rather than insulin insensitivity, is the primary defect in familial type 2 diabetes. Lancet 1986;ii:360-3.

14 Hosker JP, Matthews DR, Rudenski AS, et al. Continuous infusion of glucose with model assessment: measurement of insulin resistance and beta cell function in man. Diabetologia 1985;28:401-11.

15 Metropolitan Life Insurance Company. Net weight standards for men and women. Stat Bull Metrop Insur Co 1959;40:1-4.

16 Albano J, Ekins RP, Maritz J, Turner RC. A sensitive, precise radioimmunoassay of serum insulin relying on charcoal separation of bound and free moieties. Acta Endocrinol (Copenh) 1972;79:487-509.

17 Holman RR, Turner RC. Diabetes: the quest for basal normoglycaemia. Lancet 1977;i:469-74.

18 Bottazzo GF, Florin Christensen A, Doniach D. Islet cell antibodies in diabetes mellitus with auto-immune polyendocrine deficiencies. Lancet 1974;ii:1279-82.

19 Tattersall R, Fajans SS. Diabetes and carbohydrate tolerance in 199 offspring of 37 conjugal diabetic parents. Diabetes 1975;24:452-62.

20 Kahn CB, Soeldner JS, Gleason RE, Rojas L, Camerini-Davalos RA, Marble A. Clinical and chemical diabetes in the offspring of diabetic couples. $N$ Engl F Med 1969;281:343-6.

21 Cooke AM, Fitzgerald MG, Malins JM, Pyke DA. Diabetes in the children of diabetic couples. BrMed f 1966;ii:674-6.

22 Viswanathan M, Mohan V, Snehalatha C, Ramachandran A. High prevalence of type 2 (noninsulin dependent) diabetes among the offspring of conjugal type 2 diabetic parents in India. Diabetologia 1985;28:907-10.

23 Harris $\mathrm{H}$. The familial distribution of diabetes melltisu: a study of the relatives of 1241 diabetic propositi. Annals of Eugenics 1950;15:95-110.

24 WHO Expert Committe on Diabetes Mellitus. Second report. WHO Tech Rep Ser 1980;No 646. 25 Wilson RM, Van der Minne P, Deverill I, et al. Insulin dependence: problems with the classification of 100 consecutive patients. Diabetic Medicine 1985;2:167-72.

26 Tattersall RB. The present status of maturity-onset type diabetes of the young. In: Kobberling J, Tattersall RB, eds. Genetics of diabetes mellitus. London, New York: Academic Press, 1982: 261-70.

27 Asmal A, Dayal B, Jailal I, Learly W, Omar MAK, Pillay NL, Thandoroyen FT. Non-insulin dependent diabetes melltius with early onset in blacks and Indians. S Afr Med f 1981;60:93-6. 8 Efendic S, Luft R, Wajngot A. Aspects of the pathogenesis of type 2 diabetes. Endocr Rev 1985;5:395-409.

29 Chen M, Bergman RN, Pacini G, Porte D. Pathogenesis of age-related glucose intolerance in man: insulin resistance and decreased beta-cell function. $\mathcal{F}$ Clin Endocrinol Metab 1985;60: $13-20$.

30 Davis TME, Turner RC. Cigma assessment of insulin resistance and pancreatic beta-cell function in the elderly. Age Ageing 1985;14:220-4.

(Accepted 23 fanuary 1987)

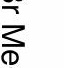 $c$ . , 椋

\section{.}

100 YEARS AGO

Comments recently published in one or two influential organs of the German press make it desirable that we should remove a misapprehension for which we may otherwise seem to be in some measure responsible. When His Imperial Highness was under active treatment in this country, we reported the progress of the case from week to week in sufficient detail to enable our readers to follow the course of events with intelligent interest, while taking care to avoid anything that might pander to unmannerly curiosity. When the illustrious patient became so far convalescent that no further operative measures were required, we thought it unnecessary to continue to publish further reports, for the simple reason that there was nothing of special importance to report. This perfectly natural proceeding seems, however, to have been misunderstood, and a sinister significance, for which there is absolutely no foundation, has been attached by the political press of Germany to the cessation of our weekly reports. If the matter were a less grave one, there might only be reason for some amusement at our silence being supposed to be fraught with a meaning as portentous as that conveyed in Lord Burleigh's famous nod. The statement which we published last week, though sufficiently precise and explicit, does not seem to have altogether dispelled the anxiety felt by our German contemporaries. We wish, therefore, to state plainly and without any diplomatic reserve or ambiguity that, according to the best authority on the subject, the Crown Prince's condition is, up to this morning, highly satisfactory. There is no recurrence whatever of the growth; the functions of the parts are not interfered with in the slightest degree, except that the voice is still rather weak; there is no appearance or sensation in the throat that need cause either alarm in the present or well-grounded apprehension as to the future. More than this it is clearly impossible for any man, however experienced, to say; and vague fears as to what may lie "behind the veil" in this or any other case are hardly fit matter for public discussion. The Prince suffers, as we have already stated more than once, from somewhat marked irritability of the upper air-passages, which leads to his "taking cold" very easily; and whilst at Toblach he had a sharp attack of inflammation, not only of the larynx, but of the trachea. It is obviously impossible in any climate entirely to guard against sudden changes of temperature, but it is right to say that Toblach, which has many advantages, was chosen as a place of residence by the Prince and 은 Princess themselves, who had been there before and liked it. As the weather $N$ at Baveno has lately become rather inclement, the Prince will shortly proceed to San Remo, where he will probably spend the winter. In conclusion, we may add that, as some doubt has been suggested how far the reports which we have published from time to time represent the opinions of Sir Morell Mackenzie, we have his authority for saying that we have throughout expressed his views with perfect accuracy. (British Medical foumal 1887;ii:899)

The overcrowding of the carriages, especially the third-class carriages, on the Underground at certain hours of the day, is a serious grievance to many Londoners, but the companies make no effort to check the practice, which is dangerous to life and limb. It may therefore be well to point out that there is a remedy which it ought not to be difficult to enforce. One of the by-laws and regulations made by the Metropolitan Railway Company, with the approval $O$ of the Board of Trade in 1874, runs thus: "Any passenger persisting in entering a carriage or compartment of a carriage containing the full number of persons which it is constructed to carry when any such person objects to his so entering the carriage or compartment, is hereby subjected to a penalty not exceeding forty shillings." (British Medical fournal 1887;ii:1121.) 